\section{Laadullinen tutkimus seisoo omilla jaloillaan}

Anu Puusa \& Pauli Juuti (toim.) (2020). Laadullisen tutkimuksen näkökulmat ja menetelmät. Gaudeamus. 380 sivua.

LAADULLINEN TUTKIMUS on nopeasti kehittyvä ja laajeneva ihmisja yhteiskuntatieteiden alue, joten uusi teos on paikallaan. Tämäntapaisia, suomenkielisille lukijoille osoitettuja opastuksia on ilmestynyt määräajoin aiempia esityksiä rikastaen ja päivittäen.

Aikuiskasvatustutkimuksen opettajana odotan, että "Puusa \& Juuti 2020" ilmaantuu viitatuksi menetelmälähteeksi aiempien rinnalle ja saan teoksesta apuopettajan ja helpotusta opiskelijakohtaiseen sähköpostiohjaukseen. Toimittajat ovatkin ajatelleet sekä perus- ja jatko-opiskelijoiden että opetusta antavien tarpeita.

\section{MISSÄ TUTKIMUSETIIKKA JA TIETOTURVA?}

Teos jakautuu kuuteen osaan, joiden asiasisällöt etenevät loogisesti tieteenfilosofisista taustaoletuksista tarkempien ominaispiirteiden kuvaukseen, sitten aineiston hankintamenetelmiin, analysointiin ja luotettavuusnäkökohtiin. Viimeinen osa esittelee kattavasti laadullisen tutkimuksen lähestymistapoja: tapaustutkimuksen, narratiivisen lähestymistavan, diskurssianalyysin, grounded theoryn aineistolähtöisyyden, toimintatutkimuksen, autoetnografian, fenomenologian ihmisten kokemusten tutkimisessa, monimene- telmätutkimuksen sekä poststrukturalismin organisaatioiden tarinoiden tutkimuksessa.

Vaikka tutkimuksen ja tutkijan eettisyys kulkee yleisasenteena läpi teoksen, se on omana alueenaan rajattu esityksen ulkopuolelle. Ehkä ei ole haluttu toistaa muualla esitettyjä periaatteita ja ohjeita. Tutkimusetiikka ja tietoturva ovat kuitenkin aivan viime vuosina eniten muuttuneita ja kehittyneitä alueita, joiden toteuttaminen laadullisessa tutkimuksessa herättää erityiskysymyksiä, kuten tutkimuksen teon muutkin osaalueet. On tiedettävä, mitä tutkimukseen osallistuvien informoitu suostumus tarkoittaa ja edellyttää, miten laadullisen aineiston elinkaari voidaan suunnitella ja onko aineiston anonymisointi ja avoin julkaiseminen mahdollista.

\section{LAADULLISEN TUTKIMUKSEN SUBJEKTIIVISUUS KOROSTUU}

Kirjan aloittava toimittajien tieteenfilosofinen katsaus ja laadullisen tutkimuksen taustaoletusten tarkastelu on tieteenfilosofinen pikakurssi, joka lisää teoksen käyttöarvoa opetuksessa. Jouni Kekäle ja Anu Puusa valottavat tiedesotia ja linjaavat laadullista tutkimusta realistisen ja konstruktionistisen maailmankäsityksen rajanvedolla. Toisessa osassa laadullisen

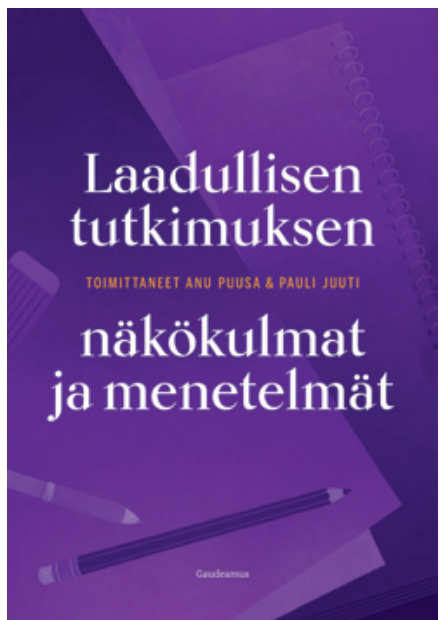

tutkimuksen ominaispiirteitä havainnollistetaan esimerkein ja vastataan kysymyksiin, jotka tyypillisesti askarruttavat aloittelevaa tutkijaa.

Toimittajista Puusa on aineettoman pääoman professori ItäSuomen yliopistossa ja Juuti johtamisen ja organisaatioiden emeritusprofessori Lappeenrannan teknillisessä yliopistossa. Teos on kirjoitettu ennen muuta kauppatieteen piirissä tehtävää organisaatio- ja liiketaloustieteellistä tutkimusta ajatellen ja sen kokemuspiiristä ammentaen. Tämä saattaa osin selittää kirjan läpi kulkevan laadullisen tutkimuksen subjektiivisuuden korostamisen. Onhan aikoinaan objektiivisuutta korostanut organisaatiotutkimus kauppatieteen laadullisen tutkimuksen keskeinen taustavaikuttaja ja sovellusala (s. 59).

Kolmas osa ohjaa laadullisen aineiston yleisimpiin hankintamenetelmiin, haastatteluihin, ryhmäkeskusteluihin ja havainnointiin. Tyyli on käytännönläheistä ja järkeenkäypää; opinnäytetyötään 


\section{TUTKIMUKSEN JA TUTKIJAN EETTISYYS KULKEE \\ YLEISASENTEENA LÄPI TEOKSEN.}

aloittava opiskelija saa menetelmistä hyvän yleiskuvan. Lisäksi olisi mielellään lukenut esimerkkejä erilaisten haastattelu- ja havainnointi-instrumenttien rakentamisesta. Tässä, kuten kirjan muissakin osissa, luvun soisi päättyvän opastavaan ja huomioonotettavien asioiden tiivistelmään ympäripyöreän "Lopuksi" toteamuksen sijaan.

\section{SELKEÄ OTE AINEISTON ANALYYSIIN}

Laadullisen aineiston analysoinnilla on kirjassa oma, kaksi lukua käsittävä osansa. Tosin samaa tehtävää palvelee viimeinen, eri tutkimuslähestymistapoja esittelevä laaja osa. Puusan selkeä ja opastava teksti perehdyttää laadullisen aineiston analysoinnin yleisiin näkökulmiin. Ote on aineistolähtöinen kuten laadulliseen tutkimukseen sopii. Silti kaipaisin katseen kääntämistä niin sanotusti ympäröivään todellisuuteen.

Periaatteessa faktanäkökulma suuntautuu puheen kohteen ja näytenäkökulma puheesta avautuvien tulkintojen analysointiin (s. 150). Erottelu tuntuu keinote- koiselta ja jättää laadullisen aineiston ja sen analyysin todellisuussuhteen hämäräksi. Tätä vasten Leena Kosken dialogiseen tematisointiin perustuvan analyysitavan esittely on kuin toisesta maailmasta. Hän viittaa muitta mutkitta metodologiseen realismiin, jossa katsotaan yhteiskunnallisten mekanismien määrittävän ihmisten toimintaa ja vastaavasti yksilöiden rakentavan yhteiskunnan mekanismeihin erilaisia suhteita (s. 160). Tämän jälkeen tutkija avaa Kolin alueen naisyrittäjiä käsittelevän tutkimusesimerkin avulla metodologiset ja metodiset valintansa, joita lukijan on mahdollista seurata ja arvioida.

\section{MONIPUOLISESTI TUTKIMUKSEN LUOTETTAVUUDESTA}

Laadullisen tutkimuksen luotettavuus on käsitelty monipuolisesti, ja opiskelija löytää teoksesta hyvät kriteerit opinnäytteeseensä. Tutkimusetiikan ja tietoturvan kriteerit on kuitenkin syytä täydentää muista lähteistä. Samoin pohdittavaksi jäävät laadullisen tutkimuksen validiteetin ja reliabiliteetin arvioinnin tavat ja yli- päätään mahdollisuus, sillä tässä näkökohtia esitetään sekä puolesta että vastaan. Viimeisen osan erilaiset tutkimuslähestymistavat avaavat laadullisen tutkimuksen rikasta kenttää. Toimitustyöhön on jäänyt hienoista rosoisuutta.

Yksittäistapaustutkimus, narratiivinen lähestymistapa ja moni muu luku ovat yleisjohdatteluja, kun taas diskurssianalyysi herää eloon aineistoesimerkkien valossa. Fenomenologia ja poststrukturalismi palaavat kirjan alkuosan teemoihin.

Loppusanoissaan toimittajat toivovat kirjan auttavan tutkimustyötä opettelevia välttämään ihmisen pelkistämistä numeroiksi, malleiksi tai luokiksi (s. 335). Minusta tällainen keskustelu jää kirjassa taka-alalle. Kirjoittajat osoittavat, että laadullinen tutkimus seisoo tieteen maailmassa omilla jaloillaan. Tulkinnallisella otteella on vankka asemansa, haluaisin lisätä: tiedon tuottamisessa jaetusta todellisuudestamme.

\section{HANNA TOIVIAINEN}

FT, aikuiskasvatuksen professori Tampereen yliopisto

(D) https://orcid.org/0000-00021782-8678 